\title{
An Assessment of the Seismic Performance of the Historic Tigris Bridge
}

\author{
Atila Kumbasaroglu, Alper Celik*, Osman Demir, Ahmet Ihsan Turan, Hakan Yalciner \\ Civil Engineering Department, Erzincan University, Erzincan, Turkey \\ Email: *alper.celik@erzincan.edu.tr
}

How to cite this paper: Kumbasaroglu, A., Celik, A., Demir, O., Turan, A.I. and Yalciner, H. (2019) An Assessment of the Seismic Performance of the Historic Tigris Bridge. Open Journal of Civil Engineering, 9, 230-239.

https://doi.org/10.4236/ojce.2019.93016

Received: May 1, 2019

Accepted: September 13, 2019

Published: September 16, 2019

Copyright $\odot 2019$ by author(s) and Scientific Research Publishing Inc. This work is licensed under the Creative Commons Attribution International License (CC BY 4.0).

http://creativecommons.org/licenses/by/4.0/

\begin{abstract}
Turkey is a country that is vulnerable to earthquakes and has experienced many major earthquakes that completely destroyed or caused significant damage to numerous historic structures. Today, using computer software, it is important to numerically model and analyze historic structures that need significant restoration and strengthening, to evaluate them from a perspective of seismic resistance, and to reinforce them without altering their originality. In this study, a finite element model of the historic Tigris Bridge on the Tigris River was created. First, the stresses and deformation caused by its own weight were determined. Subsequently, dynamic analyses were performed in the time domain using past earthquake ground motion records. Displacement and stress values obtained for each earthquake record in these time domain analysis were compared to each other to evaluate the seismic behavior of the bridge comparatively. The seismic performance of the bridge was determined on the basis of the "Guidelines on the Management of Earthquake Risks for Historic Structures" published by the Directorate General of Religious Foundations in Turkey.
\end{abstract}

\section{Keywords}

Seismic Performance of Historic Buildings, Historic Bridge, Time Domain Analysis

\section{General Features of the Structure}

\subsection{Location and History of the Bridge}

The historic Tigris Bridge in Diyarbakır is an important and prominent structure in terms of its size and architecture and has become a symbol of the said city. The bridge is $3 \mathrm{~km}$ from the city center and is located at a point that links the center of the city to the Township of Bağıvar and several villages. Several 
opinions have been expressed about the date when the bridge was first built. According to Van Bercheh and Albert Gabriel, another bridge stood in the current location of the Tigris Bridge in ancient times [1]. An epitaph stating that in Diyarbakır, which came under Islamic rule in 639, Umayyad Caliph Hisham started repairing a collapsed bridge in 742 - 743 and that the construction work stopped after his death. It is also known that the eastern armies of the Roman Empire besieged Diyarbakir unsuccessfully in 974 and that they destroyed this bridge when they withdrew [2].

The bridge is believed to have been destroyed and rebuilt partially or completely several times. The most recent and most accurate known construction date of the bridge is based on the inscription marked on the bridge. According to this inscription, the bridge was built in 457 A.H. (1065 AD).

\subsection{Architectural Review of the Bridge}

The Tigris Bridge is considered to fall in the category of multi-span flat-top bridges. The bridge is $172 \mathrm{~m}$ long. Its width varies between 5.45 and $6.24 \mathrm{~m}$ over the first five spans and increases to the range $9.69-10.20 \mathrm{~m}$ from the fifth span on. The road over the bridge is currently covered with the original paving stones following restoration. The parapet height is $85 \mathrm{~cm}$ at the end and rises to as much as $155 \mathrm{~cm}$ near the middle (Figure 1).

The capstones are nine capped pyramidal flood splitters [fender piles] stand on the north (upstream) side of the bridge. Flood splitters 1, 2, 3, and 4 (S1, S2, S3, S4) are lower in height than the others. Also, the spandrel walls of the spans $6,7,8,9$, and 10 retain their original construction features up to half their heights. However, different masonry work has been applied to the spandrel walls of the spans 1, 2, 3, 4, and 5 as shown in Figure 2 and Figure 3.

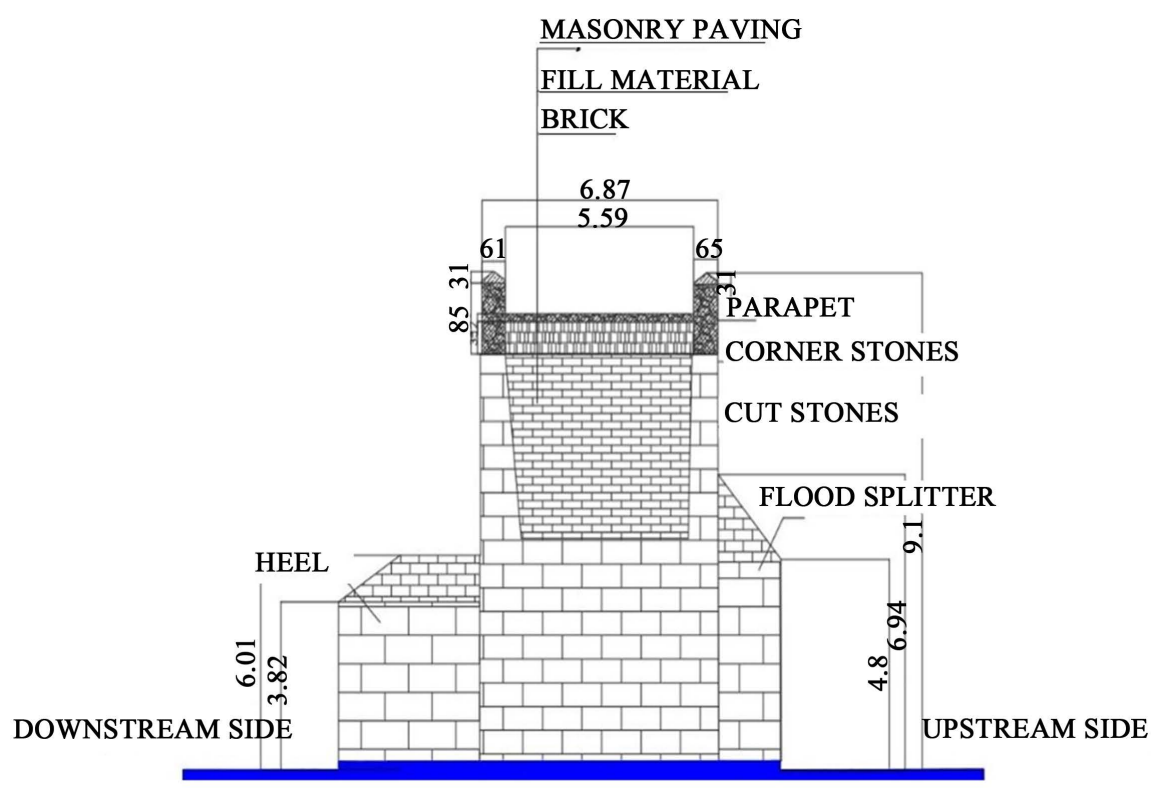

Figure 1. Cross Section Drawing (Halifeoğlu et al., 2009c). 


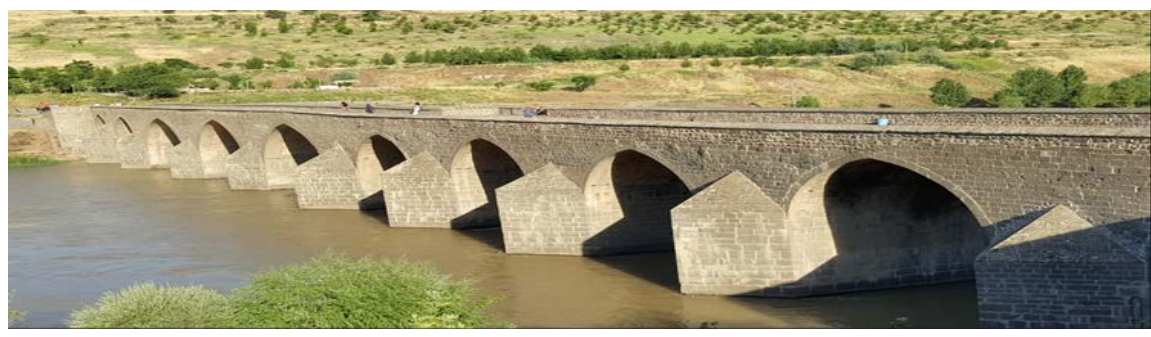

Figure 2. Capped pyramidal flood splitters on the upstream face.

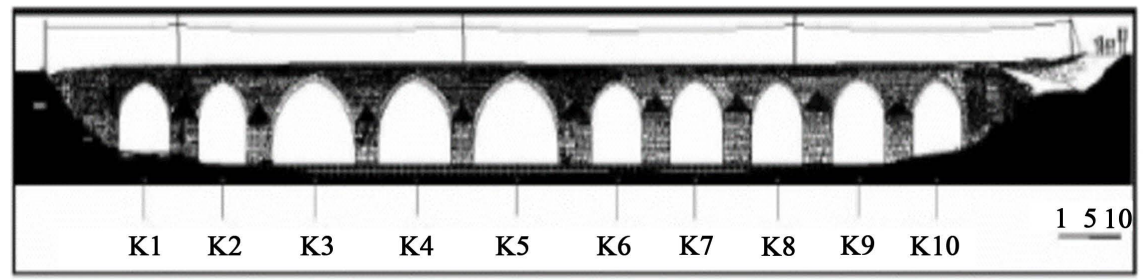

Figure 3. Upstream facade-elevation drawing [3].

Unlike the north side, the southern (downstream) side of the bridge does not feature a flat facade wall. The arches of the spans 1,2,3, 4, and 5 are recessed by around $4 \mathrm{~m}$. Following a study of traces left on the current bridge, it was determined that this section collapsed after [it was initially built] and that it was built with recesses during repairs (Figure 4).

The bridge features 29 different masons' marks in the form of different symbols. In addition to these, two different arrays of markings are inscribed as blocks. One of these is an array where the Latin characters $\mathrm{K}, \mathrm{O}$, and $\mathrm{E}$ are listed one below the other. The other consists of blocks of points arrayed vertically, horizontally, and diagonally. The masons' marks may be interpreted as signifying the purpose of the construction, the calculation of the stones mined from quarries, differentiation of different types of marbles, identification of marble traders, and identification of the artisans who hewed the stones [4].

\subsection{Determination of the Material Properties of the Bridge}

The determination of structural behaviors and material properties is an important step in engineering studies conducted for the purpose of transferring historic structures to future generations. Because materials used in masonry construction work are of a composite nature and because similar elements exhibit different material properties, the determination of the material properties of a structure is often quite difficult. In general, basalt, a local material, was used in the construction of the Tigris Bridge. Smoothly cut basalt stone was used in the spans $6,7,8,9$, and 10 up to half the height of the bridge until the arched sections. However, rubble stone was used for repairs of the arch keystones and sometimes from the joist hanger above the arch to the wall capstone. Material parameters for use in the finite element analysis of the Tigris (Ten Span) Bridge in Diyarbakir were determined from previous studies on the bridge, and the analysis was performed based on these values (Table 1). 


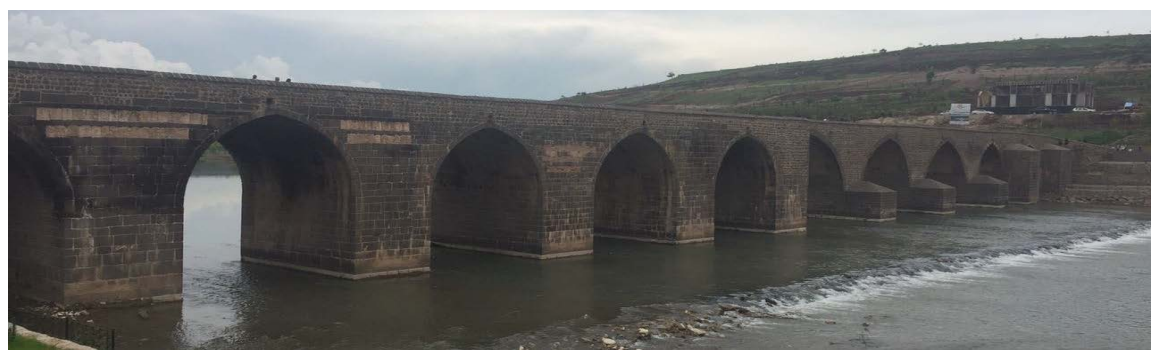

Figure 4. View of the downstream facade of the historic Tigris Bridge.

Table 1. Material properties used in the analysis [5].

\begin{tabular}{cccc}
\hline Material & Elastic Modulus $(\mathrm{MPa})$ & Poisson's Ratio & Density $\left(\mathrm{kN} / \mathrm{m}^{3}\right)$ \\
\hline Stone & 3500 & 0.2 & 16 \\
Brick & 3000 & 0.3 & 12 \\
Corner Stones & 2500 & 0.2 & 14 \\
Fill material & 500 & 0.05 & 12 \\
\hline
\end{tabular}

\section{Modeling and Analysis of the Structure}

The historic bridge was modeled using "Finite Element Analysis", which facilitates the definition of cross-sectional and material properties of structural elements with different geometries, on the computer program SAP2000 (Version 15). Static analysis was used to determine the behavior of the structure due to its own weight; modal analysis was used to determine the mode shapes and natural periods of the structure; and linear analysis in the time domain was used to determine the behavior of the structure under dynamic loads using acceleration data for the March 13, 1992 Erzincan Earthquake.

\subsection{Creation of the Three-Dimensional Finite Element Model of the Bridge}

In finite element modeling, the geometry of the structure or structural elements is determined by a finite number of nodes. To determine the behavior of the structure accurately, a large number of nodes were used in creating a finite element model of the Tigris Bridge. Specifically, 12,937 solid elements and 17,541 nodes were used in the finite element model created. For this study, the degrees of freedom at the base of the bridge were assumed to be fixed. The finite element model created for the Tigris Bridge is shown in Figure 5.

\subsection{Gravity Load Analysis}

Gravity load analysis is important in terms of observing the distribution of stresses and deformations caused by the weight of the structure. In general, although structures are expected to carry vertical loads safely, any potential problems and deficiencies can be easily seen and the necessary countermeasures taken through such analysis. Dead loads were defined through the specific 


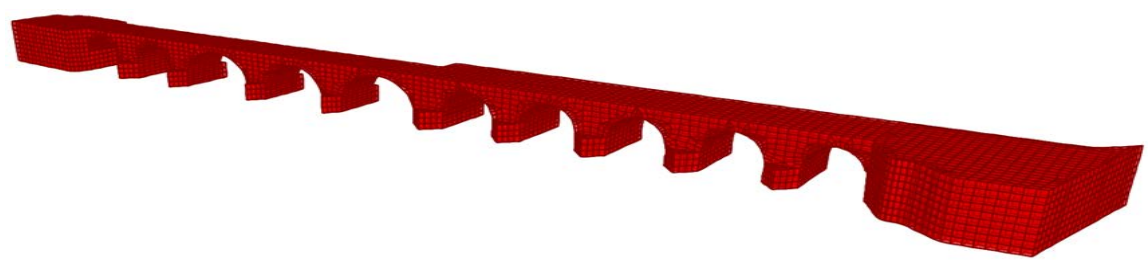

Figure 5. Finite element model of the Tigris bridge.

weights of the materials in this study. Live loads and snow loads were not included in the calculations. The static analysis results showed that the largest displacements occurred in the vertical axis 3 (z-axis) direction in the arch footings and masonry infill walls, particularly in the arches and footings associated with the wider and taller spans 3,4 , and 5 . The largest displacement was found to be $0.852 \mathrm{~mm}$.

The distribution of maximum compressive stresses obtained from the static analysis shows that the largest stresses occur at the points where stone arches meet the footings of the bridge and at the bottoms of the footings. The largest stress was found to be $0.618 \mathrm{MPa}$ (Figure 6).

\subsection{Dynamic Analysis}

In the finite element model created by macro modeling technique, dynamic analyzes were performed. In the model, the damping ratio is constant $5 \%$. Within the scope of dynamic analysis, modal analysis and time history analysis were performed.

\subsubsection{Modal Analysis}

In the modal analysis, the first five modes of the Tigris Bridge were considered to calculate mode shapes and natural frequencies, which constitute the dynamic characteristics of the bridge. Table 2 lists the natural period values and mass participation factors. When we look at the mode shapes corresponding to the listed natural frequency values, we find that the first and second modes are $\mathrm{y}$-direction lateral modes, the third and fourth modes are $\mathrm{x}$-direction lateral modes, and the fifth mode is a $\mathrm{z}$-direction vertical mode (Table 2).

\subsubsection{Time Domain Analysis}

A time domain finite element dynamic analysis was performed on the model that was created using a macro-modeling technique. Acceleration data for the east-west component of the March 13, 1992 Erzincan Earthquake were applied to the model to simulate the behavior of this structure under dynamic loads. The largest acceleration [in the earthquake record] was $-470.915 \mathrm{~cm} / \mathrm{s}^{2}$ at 3.395 seconds (Figure 7).

1992 Erzincan Earthquake in cases where the choice of sufficient score and quantity of earthquake records cannot make, simulated ground motions are used considering the local ground conditions. The major seismic activity occurred in the region is the Erzincan Earthquake in 1992. In the linear time history analysis 


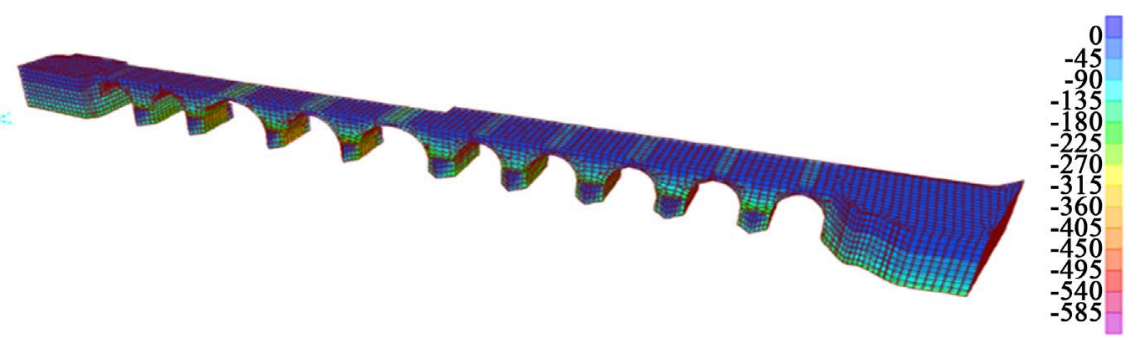

Figure 6. Gravity load analysis—-maximum compressive stresses (Mpa).

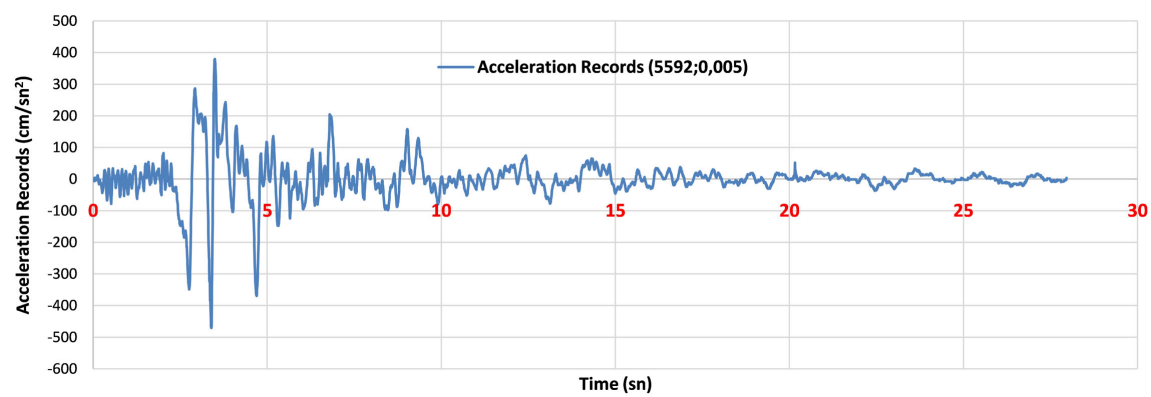

Figure 7. East-west component of the Erzincan Earthquake.

Table 2. Natural periods and natural frequencies response to each mode number.

\begin{tabular}{ccc}
\hline Mode number & Natural frequency $(\mathrm{Hz})$ & Natural period $(\mathrm{s})$ \\
\hline 1 & 8.740 & 0.114 \\
2 & 9.229 & 0.108 \\
3 & 10.165 & 0.098 \\
4 & 10.378 & 0.096 \\
5 & 11.560 & 0.086 \\
\hline
\end{tabular}

of the structure, Erzincan Earthquake record was used considering the similarity of local ground conditions. The distributions of stresses and maximum shear stresses that were obtained in the linear dynamic analysis in the time domain using acceleration records of the east-west component of the March 13, 1992 Erzincan Earthquake are shown in Figure 8 and Figure 9.

The dynamic analysis for the Erzincan earthquake calculated the maximum shear stress in the $\mathrm{x}-\mathrm{x}$ direction as $0.507 \mathrm{MPa}$, the maximum shear stress in the $\mathrm{y}-\mathrm{y}$ direction as $0.180 \mathrm{MPa}$ and the maximum shear stress in the $\mathrm{z}-\mathrm{z}$ direction as $0.893 \mathrm{MPa}$.

Maximum stresses in the $\mathrm{X}$ direction were observed in the arches of the bridge and the paved area above the arches; maximum stresses in the $\mathrm{Y}$ direction were observed at the footings of the arches, the edges of the base of the bridge, and the inner portions of the arches; maximum stresses in the $\mathrm{Z}$ direction were observed at the edges of the bases of the footings where the arches meet.

\section{Determination of the Performance of the Structure}

The performance of the structure was determined based on the performance 

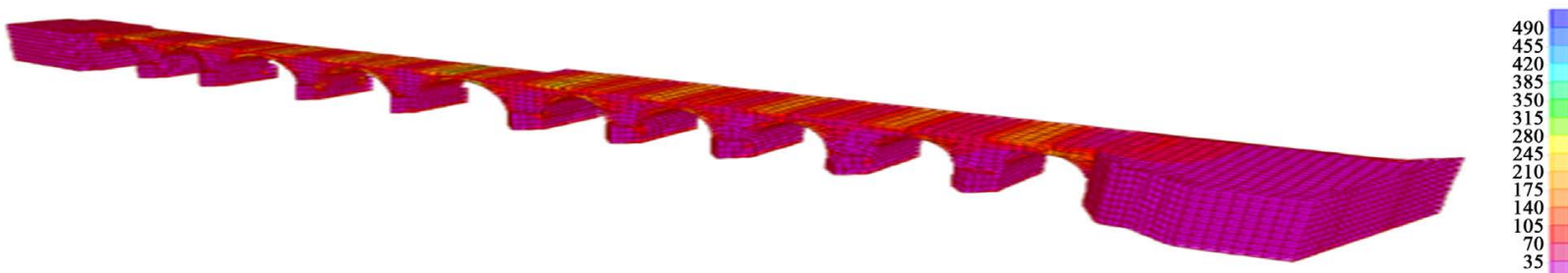

Figure 8. X-dir shear stress values for the Erzincan Earthquake (MPa).
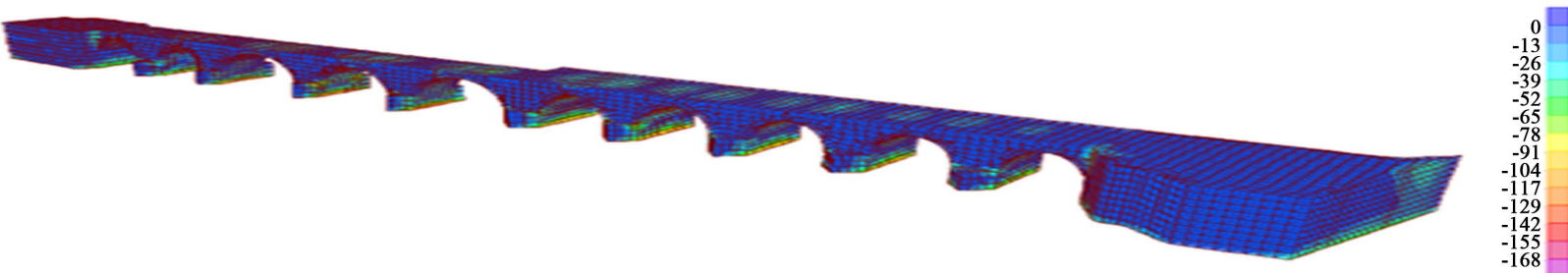

Figure 9. Y-dir shear stress values for the Erzincan Earthquake (MPa).

limit conditions specified in the "Turkish Guidelines on the Management of Earthquake Risks for Historic Structures (Table 3)”.

\subsection{Compressive Strength Safety of the Masonry Wall System}

The masonry walls in the structure are made up of mostly pitch-faced and cut stones. The material mechanical properties table provided in the Structural Modeling and Assessment section of the "Turkish Guidelines on the Management of Earthquake Risks for Historic Structures" was used to determine the compressive strength of cut stone. The table recommends a compressive strength of 1.1 to $1.6 \mathrm{MPa}$ (Table 4 ).

The maximum compressive stress that develops in the structure is $0.618 \mathrm{MPa}$, which does not exceed the compressive strength specified for masonry walls.

\subsection{Shear Strength Safety of the Masonry Wall System}

According to Section 11 of the Turkish Building Earthquake Regulation, the characteristic wall shear strength, $f_{v k}$, must be calculated from tests conducted on wall samples or the following equation.

$$
f_{v k}=f_{v k o}+0.4 \sigma_{d} \leq 0.10 f_{b}
$$

where, $f_{v k}$ is the characteristic wall shear strength using vertical stresses on the wall, $f_{v k o}$ is the characteristic shear strength when no axial stresses are present, $\sigma_{d}$ is the vertical compressive stress calculated under the combined effect of vertical loads multiplied by load coefficients and earthquake loads and $f_{b}$ is the standardized average compressive strength of masonry element (equivalent to non-dimensionalized $100 \times 100 \mathrm{~mm}$ sample).

The characteristic shear strength $\left(f_{v k}\right)$ when axial stresses are not present must be determined based on Turkish Building Earthquake Regulation (Table 5).

Shear strengths for stones are given in $0.10 \mathrm{MPa}=100 \mathrm{kN} / \mathrm{m}^{2}$. Effective shear 
stresses in the walls were obtained from maximum compressive stresses $\left(\sigma_{d}\right)$ in the structure based on the results of the analysis under vertical loads Shear stresses calculated in walls in time domain analyses were compared to calculated shear strengths (Table 6).

Table 3. Performance level [6].

\begin{tabular}{|c|c|}
\hline Performance level & Calculation method and limits \\
\hline \multirow{5}{*}{$\begin{array}{c}\text { Limited } \\
\text { damage limit } \\
\text { condition (LD) }\end{array}$} & 1) Linear calculation method used; \\
\hline & a) Calculated strengths subjected to vertical loads and undamped \\
\hline & projected earthquakes not exceeded. \\
\hline & b) The sidesway ratio under undamped earthquake loading does \\
\hline & not exceed the $0.3 \%$ limit. \\
\hline \multirow{8}{*}{$\begin{array}{c}\text { Controlled } \\
\text { damage limit } \\
\text { condition }(C D)\end{array}$} & 1) Linear calculation method used; \\
\hline & a) Calculated strengths subjected to vertical loads and projected \\
\hline & earthquakes damped by $R_{a} \leq 3$ not exceeded. \\
\hline & b) The sidesway ratio under undamped earthquake loading \\
\hline & does not exceed the $0.7 \%$ limit. \\
\hline & 2) Nonlinear calculation method used; \\
\hline & a) The sidesway ratio does not exceed the $0.7 \%$ limit. \\
\hline & b) The deformation capacities of the materials not exceeded. \\
\hline \multirow{8}{*}{$\begin{array}{l}\text { Pre-collapse } \\
\text { limit condition } \\
\text { (PC) }\end{array}$} & 1) Linear calculation method used; \\
\hline & a) Calculated strengths subjected to vertical loads and projected \\
\hline & earthquakes damped by $\mathrm{R}_{\mathrm{a}} \leq 3$ may be exceed to some extent ( $\sim 1.5$ times). \\
\hline & b) The sidesway ratio under undamped earthquake loading does not \\
\hline & exceed the $1 \%$ limit. \\
\hline & 2) Nonlinear calculation method used; \\
\hline & a) The sidesway ratio does not exceed the $1 \%$ limit. \\
\hline & $\begin{array}{l}\text { b) The deformation capacities of the materials may be exceeded } \\
\text { by a limited amount ( } 1.2 \text { times }) \text {. }\end{array}$ \\
\hline
\end{tabular}

Table 4. Compressive strengths of masonry wall materials [6].

\begin{tabular}{cc} 
Wall Type & $\begin{array}{c}\text { Compressive Strength } \\
\mathrm{f}_{\mathrm{m}}(\mathrm{MPa})\end{array}$ \\
\hline Masonry wall built with rubble stone & $0.6-0.90$ \\
Masonry wall built with pitch-faced stone & $1.1-1.6$ \\
Masonry wall built with well-jointed cut stone & $1.5-2.0$ \\
Masonry wall built with soft stone (limestone, tufa) & $0.8-1.2$ \\
Masonry wall built with plastered smooth-cut stone & $3.0-4.0$ \\
Masonry wall built with brick and lime mortar & $1.8-2.8$ \\
Masonry wall built with semi-hollow brick and cement mortar & $3.8-5.0$ \\
Masonry wall built with bricks with void ratio of less than $45 \%$ & $4.6-6.0$ \\
\hline
\end{tabular}

Table 5. Initial shear strengths of walls, $f_{v k o}(\mathrm{MPa})[7]$.

\begin{tabular}{ccc}
\hline Masonry element & General purpose mortar $\left(^{*}\right)$ & Thin layer mortar \\
\hline Brick & M2.5 - M9 0.30 & 0.20 \\
& M1 - M2 & 0.10 \\
Concrete & M10 - M20 0.30 & 0.20 \\
Aerated concrete & M2.5 - M9 0.30 & 0.15 \\
Natural or synthetic stone & M1 - M2 Not used & 0.10 \\
\hline
\end{tabular}

$\left.{ }^{*}\right)$ The mortars are labeled such that the number following the letter $\mathrm{M}$ indicates the characteristic compressive strength in MPa. 
Table 6. Shear safety in the masonry wall system under earthquake loading.

\begin{tabular}{ccccc}
\hline Direction & $\begin{array}{c}\text { Compressive stress } \\
\text { developed (MPa) }\end{array}$ & $\begin{array}{c}\text { Shear stress } \\
\text { developed (MPa) }\end{array}$ & $\begin{array}{c}\text { Effective shear } \\
\text { strength (MPa) }\end{array}$ & Safety status \\
\hline $\mathrm{X}-\mathrm{X}$ & 0.618 & 0.507 & 0.347 & Insufficient \\
$\mathrm{Y}-\mathrm{Y}$ & 0.618 & 0.180 & 0.347 & Sufficient \\
\hline
\end{tabular}

\subsection{Control of Maximum Drift Ratio in the Structure}

The maximum displacement in the structure in analyses performed using earthquake impact was calculated as $2.199 \mathrm{~mm}$. The maximum drift ratio of the structure is $0.02 \%$ which is less than the limited damage limit state acceptance criteria described above.

\section{Conclusions}

Turkey is an active seismic country. Therefore, earthquakes can be devastating for historical buildings. Damages caused by earthquakes can be manifested by cracks in the arches. Stones are strong in compression and somewhat so in shear, but cannot resist much force in tension, thus masonry arch bridges are designed to be constantly under compression. Furthermore, lateral loads may also be applied to the bridges in addition to vertical loads due to earthquake effects in seismic areas. Consequently, lateral displacements may also occur and cause damage [8].

Maximum potential stresses and displacements in the Tigris Bridge were determined through static and dynamic analysis performed on a finite element model of the historic structure. The performance level of the structure was determined using calculation methods that correspond to performance levels and limit conditions specified in the "Turkish Guidelines for the Management of Earthquake Risks for Historic Structures" based on the findings below. Compressive stresses that were calculated in the static analysis under vertical loads do not exceed the compressive strength. Shear stresses in the X-X direction, determined in an analysis performed under real earthquake loading, exceed the effective shear strength. However, this earthquake loading, was not reduced by a response modification factor " $\mathrm{R}$ " factor. Shear stresses in the Y-Y direction, determined in an analysis performed under undamped real earthquake loading, do not exceed the effective shear strength. The calculated maximum drift ratio of $0.02 \%$ in the structure does not exceed the $0.3 \%$ drift limit. Stresses that develop in the structure under undamped earthquake loading (Erzincan 1992) exceed the calculated strengths only $\mathrm{X}$ direction. But, stresses that develop in the structures under damped with $\mathrm{Ra}<3$ earthquake loading do not exceed the calculated strengths. Besides, because the drift ratio does not exceed the damage situation that will occur in the case of a mid-sized earthquake that may occur during the service life of the historic Tigris Bridge will remain within the limits of controlled damage. The "Turkish Guidelines on the Management of Earthquake 
Risks for Historic Structures" should be used for the detection and repair of damage after the earthquake.

\section{Conflicts of Interest}

The authors declare no conflicts of interest regarding the publication of this paper.

\section{References}

[1] Beysanoğlu, Ş. (1996) Anttlarıve Kitabeleriile Diyarbakır Tarih, Ankara.

[2] Çulpan, C. (2002) Türk Taş Köprüleri, Ortaçağdan Osmanlı Devrine Kadar, Türk Tarih Kurumu, Ankara.

[3] Halifeoğlu, F.M., Dalkılıç, N., Sert, H. and Halifeoğlu, Z. (2009) Diyarbakır, Dicle (On Gözlü) Köprüsü’nün Rölöve, Restitüsyonve Restorasyon Projelerinin Yapımı, Uluslararası Katılımlı Tarihi Eserlerin Güçlendirilmesive Geleceğe GüvenleDevredilmesi Sempozyumu, Diyarbakır.

[4] Bakırer, Ö. (2002) Anadolu Selçuklu Mimarisinde TaşçıIş̧aretleri, Uluslararası Sanat Tarihi Sempozyumu, Prof. Dr. Gönül Güney’e Armağan.

[5] Demir, A., Gedik, H., Güneş, O. and Korkmaz, K. (2016) Structural and Seismic Evaluation of Historical Dicle Bridge in Turkey. Istanbul Technical University, Department of Architecture, Taskisla, Turkey Istanbul Technical University, Department of Civil Engineering, Istanbul, İstanbul Bridge Conference.

[6] Tarihi Yapıların Deprem Risklerinin Yönetimi Kılavuzu-Vakıflar Genel Müdürlüğü-2007 (Turkish Guidelines on the Management of Earthquake Risks for Historic Structures).

[7] Turkey Building Earthquake Regulation (2019).

[8] Ural, A., Oruç, S., Dogangün, A. and Iskender, Ö. (2008) Turkish Historical Arch Bridges and Their Deteriorations and Failures. Engineering Failure Analysis, 15, 43-53. https://doi.org/10.1016/j.engfailanal.2007.01.006 